\title{
Person-Centered Approach in the Professional Training of Future Masters of Preschool Education
}

\author{
Lubov V. Artemova \\ Oleksandr Dovzhenko Hlukhiv National Pedagogical University \\ Nataliia I. Melnyk \\ National Aviation University \\ Iryna V. Koriakina \\ Oleksandr Dovzhenko Hlukhiv National Pedagogical University \\ Veronika Ye. Abramovych \\ Kyiv International University \\ Nadiia V. Stadnik \\ Bila Tserkva Humanitarian and Pedagogical College
}

\begin{abstract}
The relevance of the research lies in the fact that the issue of student-teacher interaction in the educational process has not been sufficiently studied. Purpose of the study: to identify the possibilities of humanization and democratization of the educational process as mutual control between the teacher and the student in the implementation of a personality-oriented approach to its participants. The humanistic strategy of managing the educational process, the tactics of sub-object interaction between the teacher and the students, the personality-oriented selection of educational tasks of students, aimed at the individual selfrealization of each subject of the educational process, have become the main research methods. As a result of the research, the features of a personality-oriented approach in educational management of a teacher with a student have been determined; the methods of modern management are substantiated, which determine the self-realization of the individual in teaching and studying pedagogical disciplines.
\end{abstract}

Keywords: student, teacher, pedagogical communication, personality-oriented

\section{INTRODUCTION}

In today's Ukraine, the professional training of postgraduate students - the future specialists, involves both studying of the fundamentals and specifics of the profession, obtaining of a high level of competence as well as developing a personality capable of managing the knowledge gained and being able to apply it to corresponding professions in different positions in traditional, changed, creative conditions. Professional training of specialists in higher educational institutions of Ukraine as a whole is in accordance with the 
legislation in the field of education, the requirements related to European integration, the needs of socioeconomic changes in our society, the development of market relations that require modern management in a higher vocational school (Law of Ukraine "About the Higher Education", 2014). Accordingly, the concept, principles, management and methodology of the educational process in the higher educational institutions have been substantially changed. In particular, the management of established forms of education on the basis of the Bologna process has practically implemented the idea of democratization of classes (Melnyk, 2016; Hryniak et al., 2021; Hlushchenko and Sahaidak, 2021). Foreign and domestic researchers have theoretically and practically proved the effectiveness of the interactive methods of organization of the subject-subject interaction of the teacher with students in various forms of education, developed by them. So, to a certain extent, the idea of humanization and democratization is practically realized, since the student, who was the subject of the teaching and management activities of the teacher, turned into an active participant in the educational process, that improved the results of the latter (Melnyk, 2016).

The foregoing does not exhaust the possibilities of implementing the ideas of humanization and democratization of the educational process. In particular, only scientific and practical searches for technologies of person-centered education have just begun. The psychological background of the personcentered approach was worked out by I.D. Bekh (2015). I.S. Yakimanskaya (2000) outlined three models of person-centered pedagogy that she implements in the classes of mathematics of the general education school. However, we believe that the problem of improving the quality and effectiveness of the educational process is still not sufficiently studied. In particular, the invariable management interaction between the teacher and the student, and especially from the student's side towards the teacher. It is this factor that determines the success and effectiveness of the teacher's management activities in the process of implementing a person-centered approach to students (Kopochynska, 2020; Maad, 2021). Based on the above, in the process of research, it is necessary to solve the following tasks: to find out the essence and features of the personality-oriented approach in the educational management of a teacher with a student; substantiate the methods of modern management that determine the self-realization of the individual in teaching and studying pedagogical disciplines.

\section{MATERIALS AND METHODS}

The essence of the three-level methodology of organization and management of the educational process. Stage first consists in the fact that students study basic concepts, issues and regulations of the discipline during interactive lectures with computer presentation of the content of the topic and the solution of the corresponding tasks. The second stage implies independent non-auditing work of students on the selection of each according to their own claims for tasks of three levels of complexity, developed and proposed by the teacher, which deepen and clarify the content of the discipline studied during the lectures. Stage third consists in the fact that the systematic indirect control of the teacher with students of their individual tasks. Differentiated quantitatively - qualitative assessment of the corresponding achievements of students, taking into account the level of complexity of tasks, where the highest score deserves creative decisions. Thus, raising the level of personality-orientated self-control and self-assessment of students.

These requirements need the person-centered approach to the student as the future professionally trained worker. That is why the teacher should build the management of education and communication with students as young individuals, self-sufficient personalities who have their own intellectual level of development, unique experience, the need for self-realization, self-determination, self-development. In addition, the teacher in the process of management of the educational process should bring to him/herself the same criteria as to the students (Artemova, 2012). Of course, each person is unique. The personality manifests him/herself in various manifestations, which characterize the person. The profession of the teacher and the social role of the teacher of higher education requires to be attentive to the way the student shows him/herself. But not only the duty but also the interest in the knowledge of each student in particular should be a priority in the work of the teacher. After all, the teacher's task of communicating information to students may be in vain if you do not read the signals that spontaneously each student presents in or 
outside the audience. However, the teachers primarily focus on the content, less - on the management and method of conducting their own training lessons.

Concentrating on these basic components of educational activity, the teacher only casually draws attention to the most expressive manifestations of students, usually those who prevent him/her from teaching the content of the topic of the lesson. The delimitation from elementary feedback with students makes it impossible to know their personal manifestations and, in the end, the effectiveness of the teaching activities of the teacher. Based on the well-established concepts of I.D. Bekh (2015), Zagorodnya L.P. (2010) and others, the person-centered approach of the teacher to the student allows us to find out the student's essential nature, spiritual and moral values. The essence of the person-centered approach to the student involves: understanding the person-recognition of the person-the acceptance of the person. Understanding the person.

\section{RESULTS}

The implementation of the person-centered approach in the process of interaction between the teacher and students as the management of the educational process for the purpose of self-affirmation of students can be carried out in various forms and activities. It depends on the characteristics of each academic discipline. We consider this on an example of such pedagogical normative disciplines as "theory and practice of higher education", "pedagogy of higher education". Studying this kind of discipline gives the right to future masters to teach professional disciplines in the acquired specialty. When studying with the students the indicated and other pedagogical disciplines with the aim of preparing them as future teachers, we practically include them in person-centered training. It can be carried out in any form and by different methods. We consider at least two of these activities. At the end of consideration of the topic "Lecture form of teaching", we study with masters the development of students' competencies from the first elementary level to the fourth high creative level. For clarity, using a computer presentation, we display the Figure 1 we have created. It represents the steps by which the student can grow from the initial knowledge to the creative its use and application.

FIGURE 1

\section{LEVEL OF KNOWLEDGE AND SKILLS}

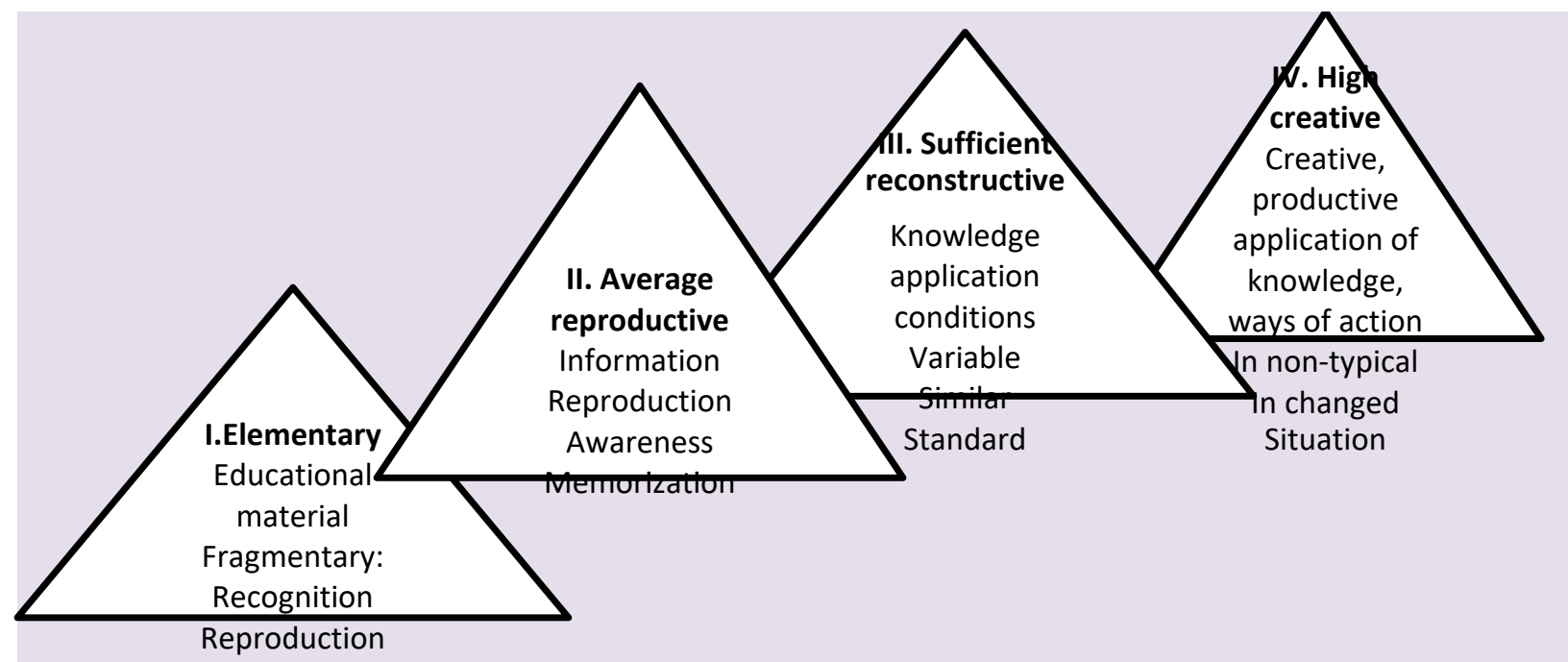

To study the table, we set a number of tasks for students: to compare the levels of growth from the first to the fourth step and assess the differences and peculiarities by the complexity of each; to assess the capabilities of your own learning activities and recognize the level at which you want and can successfully 
learn by performing the appropriate training activities. Work on these tasks develops the future teacher's individual cognitive abilities, helps them to know themselves, to self-identify and self-actualize. That is exactly what the person-centered approach provides. Written answers to these tasks by 100 students showed some differences (Table 1). The desire to study at levels II and I was showed by half of the students. At the same time, the lowest number of students were at the level I (18 \%). The level II was chosen by one third $(32 \%)$ of the students.

TABLE 1

THE RESULTS OF THE STUDY OF THE LEVEL OF DESIRED AND REAL EDUCATIONAL ACTIVITY OF STUDENTS OF THE MAGISTRACY

\begin{tabular}{|c|c|c|c|c|c|}
\hline \multirow{2}{*}{} & \multirow{2}{*}{$\begin{array}{c}\text { Level of knowledge and } \\
\text { skills }\end{array}$} & \multicolumn{2}{|c|}{ Desired level } & \multicolumn{2}{c|}{$\begin{array}{c}\text { Level of real educational } \\
\text { activity }\end{array}$} \\
\cline { 2 - 6 } & & $\begin{array}{c}\text { Amount of } \\
\text { students }\end{array}$ & $\begin{array}{c}\text { Ratio, } \\
\text { \% }\end{array}$ & Amount of students & Ratio, \% \\
\hline 1 & Elementary & 18 & 18 & 50 & 50 \\
\hline 2 & Average reproductive & 32 & 32 & 22 & 22 \\
\hline 3 & Sufficient reconstructive & 28 & 28 & 16 & 16 \\
\hline 4 & High creative & 22 & 22 & 12 & 12 \\
\hline
\end{tabular}

The choice by the students of levels II and I and the lack of desire to improve their own educational skills is explained in different ways. Some did not believe in their own capabilities. Others did not have a strong motivation to study in general. In particular, they believed that there was no sense to study pedagogical non-professional disciplines. And yet, $50 \%$ of magistracy students wanted to perform the tasks of the III and IV difficulty levels. Further, for the development and improvement of educational skills students have been offered a series of tasks for independent work in extracurricular conditions. Tasks corresponded to the topics of classroom lectures. This independent individual work was intended to deepen and practically realize the knowledge of students acquired during the lectures. The tasks were correlated by three of the above levels of complexity in Table 1: 2 - reproductive, 3 - reconstructive, 4 - creative. Naturally, we did not offer magistracy students the tasks of level 1 - the initial elementary one.

TABLE 2

TASKS FOR UNDERGRADUATE STUDENTS OF THE I COURSE, WHICH STUDY ACCORDING TO AN INDIVIDUAL PLAN FOR THE FIRST HALF OF THE YEAR. DISCIPLINE: "THEORY AND PRACTICE OF HIGHER EDUCATION" (SEMESTER I)

\begin{tabular}{|c|l|c|}
\hline № & \multicolumn{1}{|c|}{ Title of topic } & $\begin{array}{c}\text { Number of } \\
\text { points }\end{array}$ \\
\hline TOPIC 1 & $\begin{array}{l}\text { CONTENT MODULE I. State regulation of educational activities } \\
\text { Higher education, pedagogy and teaching methods in the higher school of } \\
\text { Ukraine at the present stage } \\
\text { Multiple-choice form of the task } \\
\begin{array}{l}\text { 1. Reproductive task } \\
\text { Describe the methodological foundations of the pedagogical process in higher } \\
\text { education } \\
\text { 2. Reconstructive task } \\
\text { Give examples of the application of the basic principles of the development of } \\
\text { education in Ukraine }\end{array}\end{array}$ & 7 \\
\hline
\end{tabular}




\begin{tabular}{|c|c|c|}
\hline & $\begin{array}{l}\text { 3. Creative task } \\
\text { Develop national education programs for students in and out of classroom } \\
\text { classes }\end{array}$ & \\
\hline TOPIC 2 & $\begin{array}{l}\text { Subject, purpose and tasks of the course of methodology of teaching in } \\
\text { higher education } \\
\text { Multiple-choice form of the task } \\
\text { 1. Reproductive task } \\
\text { Describe the main features of curricula, programs, textbooks for undergraduate } \\
\text { students. } \\
\text { 2. Reconstructive task } \\
\text { Find common and distinctive in curricula, programs, and textbooks for the } \\
\text { preparation of masters. } \\
\text { 3. Creative task } \\
\text { Identify from the curricula } \\
\text { a) normative educational disciplines and disciplines of the variation part of the } \\
\text { curriculum } \\
\text { b) educational disciplines of fundamental and professional training }\end{array}$ & 7 \\
\hline TOPIC 3 & $\begin{array}{l}\text { Requirements for the teacher and features of teaching for adults } \\
\text { Multiple-choice form of the task } \\
\text { 1. Reproductive task } \\
\text { Describe the main stages of teacher's preparation for the training sessions. } \\
\text { 2. Reconstructive task } \\
\text { Choose the best ways to train the teacher's personality to collaborate with } \\
\text { students in the classroom } \\
\text { 3. Creative task } \\
\text { Schedule the content and the time of the teacher's preparation for different } \\
\text { forms of training sessions }\end{array}$ & 7 \\
\hline TOPIC 4 & $\begin{array}{l}\text { Specifics of training and education of adults at a higher educational } \\
\text { institution } \\
\text { Multiple-choice form of the task } \\
\text { 1. Reproductive task } \\
\text { Describe the peculiarities of adult education } \\
\text { 2. Reconstructive task } \\
\text { Find the methods and forms of training appropriate to the characteristics of } \\
\text { adult education } \\
\text { 3. Creative task } \\
\text { Trace the personal growth and development of the student under the influence } \\
\text { of professional training in higher education }\end{array}$ & 7 \\
\hline TOPIC 5 & $\begin{array}{l}\text { Lecture form of teaching. } \\
\text { Methodical development of lecture lesson on the topic of the specialty chosen } \\
\text { by the student of the magistracy* }\end{array}$ & 7 \\
\hline \multicolumn{3}{|c|}{ CONTENT MODULE II. Organization of educational process in higher educational institutions } \\
\hline TOPIC 6 & $\begin{array}{l}\text { Seminars in higher education } \\
\text { Methodical development of seminars on the topic of the specialty chosen by the } \\
\text { student of the magistracy* }\end{array}$ & 7 \\
\hline TOPIC 7 & $\begin{array}{l}\text { Practical and laboratory classes } \\
\text { Methodical development of practical classes on the topic of the specialty } \\
\text { chosen by the student of the magistracy* }\end{array}$ & 7 \\
\hline TOPIC 8 & $\begin{array}{l}\text { Independent work of students } \\
\text { Multiple-choice form of the task }\end{array}$ & 7 \\
\hline
\end{tabular}




\begin{tabular}{|c|c|c|}
\hline & $\begin{array}{l}\text { 1. Reproductive task } \\
\text { Describe the types of independent work of students } \\
\text { 2. Reconstructive task } \\
\text { Choose the best ways of independent work of students in the classroom and } \\
\text { beyond } \\
\text { 3. Creative task } \\
\text { Plan your own independent work on the study of this discipline }\end{array}$ & \\
\hline TOPIC 9 & $\begin{array}{l}\text { Pedagogical control in the education system } \\
\text { Methodical development of laboratory classes on the topic of the specialty } \\
\text { chosen by the student of the magistracy* }\end{array}$ & 7 \\
\hline TOPIC 10 & $\begin{array}{l}\text { Pedagogical communication of the teacher with students } \\
\text { Multiple-choice form of the task } \\
\text { 1. Reproductive task } \\
\text { Describe the functions of pedagogical control } \\
\text { 2. Reconstructive task } \\
\text { Choose the methods for controlling knowledge and methods for controlling } \\
\text { abilities and skills } \\
\text { 3. Creative task } \\
\text { Apply the criteria for assessing the knowledge from the teaching and learning } \\
\text { complex of this discipline (p. } 3 \text { ) to the level of preparedness for the exam } \\
\text { (differentiated score) on the national scale and the ECTS scale }\end{array}$ & 7 \\
\hline & TOTAL POINTS & 70 \\
\hline
\end{tabular}

* The structure of the development of lectures, seminars, practical and laboratory classes, see the "Program of scientific and pedagogical (assistant) practice of students of the magistracy" (for all specialties) (2018).

TABLE 3

\section{SYSTEM OF ASSESSMENT OF STUDENT'S KNOWLEDGE BY THE CREDIT-MODULE SYSTEM ON PROGRAM OF STUDY: "THEORY AND PRACTICE OF HIGHER EDUCATION"}

\begin{tabular}{|c|c|c|c|c|c|c|c|c|c|c|}
\hline \multicolumn{10}{|c|}{ Module 1 (current control) } & \multirow[t]{4}{*}{ Amount } \\
\hline \multicolumn{5}{|c|}{ Module content I } & \multicolumn{5}{|c|}{ Module content II } & \\
\hline \multicolumn{5}{|c|}{35} & \multicolumn{5}{|c|}{35} & \\
\hline TI & $\mathrm{T} 2$ & T3 & $\mathrm{T} 4$ & T5 & T6 & $\mathrm{T} 7$ & $\mathrm{~T} 8$ & T9 & $\mathrm{T} 10$ & \\
\hline 7 & 7 & 7 & 7 & 7 & 7 & 7 & 7 & 7 & 7 & 70 \\
\hline
\end{tabular}

Note: Students who have got less than 60 points on the performance of both modules must perform a modular test and an individual task

Let's consider the features of separate groups of tasks in Table 2. In particular, we developed the tasks $1,2,3,4,8,10$ of the three levels in accordance with the levels specified in Table 1. How the students managed to fulfill these tasks see Table 2. It turned out that they for the first time met with the practical completion of tasks on a new for them reconstructive and creative levels. Before that, the students performed individual tasks at the reproductive level in the form of essays, which in fact were not a brief generalization of the text read. The so-called essays consisted of separate pieces of texts read by the students. Modern internet resources help to do this effortlessly. Since this imperfect experience was straining students, they mostly tried to use it. That is why $50 \%$ of student work turned out to be at the elementary level. I had to work individually with each student. Some did not believe in their own energies. But they wanted to learn how to work in a new way. Previously, we encouraged and supported those who wanted, but could not perform difficult tasks, emphasized the motivation for this work that was significant 
for everyone. We also helped with consultations in carrying out of tasks that gradually became more complicated; showed the examples of solutions of similar complex tasks.

The approval of the first, though insignificant progress, strongly stimulated such students and encouraged further attempts to perform complex tasks. Nevertheless, there were those who did not want to learn new things. They had to work longer individually, giving them the choice - to get a lower or higher mark for the tasks or the module. It's important to note: not everyone was stimulated by the mark, they did not want to waste their efforts and the time they spent obviously on the other. But as the educational activities of other students grew in the process of performing each of the following tasks, the most inert students also learned more complex teaching skills. Due to this, they felt better in the student group, and this is what strengthened the motivation of their choice to grow in their studying activities. The tasks 5, 6, 7, 9 are completely creative. They envisaged the creative development by the student of four forms of training sessions on the chosen topic in the specialty - lectures, seminars, practical and laboratory. To do this, the student should use the knowledge gained during the classes and from textbooks. This work should serve as a certain preparation for the next assistant pedagogical practice in accordance with the curriculum of the magistracy. In the new work for students, they met new challenges. Some students did not develop classes with the features of its methodology and recommended structure. They submitted an essay on how to build one or another lesson, but they could not actually build it, did not try or did not want to.

Such students needed explanation once more individually about the peculiarities of the methodology of conducting various forms of classes, although they already listened to all this at lectures and could read it in textbooks. Some of them subsequently offered not to count their unsuccessful work. Instead, they volunteered to make the real developments of all the classes and eventually they were made at the appropriate creative level. There were only $12 \%$ of such students in the first semester. Moreover, the assistant practice in the next semester has become a real educational incentive correctly and with adequate, interesting methods to build different classes, because it was necessary to conduct them with students of bachelor degree course. Timely, in full and at the proper level, the fulfilment of all 10 of these tasks allows us to evaluate the student's work by 70 points. These points were counted to the final grade on the exam or the test. Additional points could be obtained for a high level of task performance, and also - for successfully completed tests, during an exam or test, for the answers to the interview with the teacher. We consider, if we could continue working with these students in the following semesters on the methods considered and similar, then it would be possible to achieve better results.

\section{DISCUSSION}

Proceeding from the foregoing, in order for the process of communication to be productive, the teacher must master a lot of managerial pedagogical skills, in particular: carefully observe, adequately perceive and psychologically interpret the behaviour of the student, his/her statements, appearance, attitude to studying, teachers, and classmates; constantly read and understand the students' reaction to the image, behaviour, and academic activity of the teacher; correctly respond to the psychological interpretation of this by students; to work out a set of evaluation criteria and indicators for comparing changes in the verbal and nonverbal behaviour of students, to make appropriate pedagogical conclusions in a timely manner; objectively evaluate the own typical mistakes and skills, to improve the latter, not to allow prejudices towards students (Marchuk, 2013). At the same time, the teacher should always remember that students also study him/her. It is important to find out how each student understands the professional level of the teacher, personal manifestations, whether it will be worth the understanding of modern youth or not.

At the first stage of the person-centered approach to the student, the process of understanding the system of his/her values and qualities by the teacher determines the student's reaction to the teacher. It is the reaction of understanding each other that forms the model of interpersonal relationships between the teacher and the student. The teacher should develop his/her own social and psychological observation. The ability of the teacher to accurately perceive (or indirectly measure with sociometric methods) and to assess the relationship between students and teachers provides a wealth of material for understanding the student's personality - the motivation of his/her statements, actions, self-esteem, and attitude towards group 
members, parents, and teachers. Understanding the causes and consequences of the behavior, the student's educational activities leads to an explanation of why he/she is such, and not another, and accordingly produces an adequate assessment from the teacher and a personal attitude to each student in particular. At the same time, it is important to keep in mind the tasks that teachers need to perform in universities, and in no case be guided by their own preferences, sympathies or antipathies, prejudices. Finally, based on the student's mental capabilities and previously acquired socio-cultural characteristics, the teacher is obliged to prepare for the student, his/her parents, and relatives the socially acceptable and meaningful personality of the specialist capable of being useful to him/herself and the state (Zub et al., 2021).

In order to develop the ability to comprehensively comprehend and adequately recognize the personality that the teacher trains and develops, he/she must begin with him/herself, that is, develop his/her own reflexive and receptive skills, and the complex, which includes the knowledge of his/her own individual psychological characteristics, adequate and timely assessment of his/her mental condition, etc. (Andreyev, 2012) So, in order to recognize another (in particular, the student), you must be able to evaluate and recognize or change yourself, that is, consciously control yourself. Recognition is based on the belief in the student's capabilities, and hence on the belief in self-improvement, the understanding of his/her further, deeper and more comprehensive knowledge (Stryzhak, 2007). Thus person-centered approach to the student assumes that the teacher will recognize the student's right to be him/herself, an individual, with his/her own position regarding certain phenomena, situations, problems; as well as belief in the nobility of his/her motives and actions, in the success of studying for the chosen profession, in the right to selfrealization and the choice of his/her own way of life (Karimova and Zhetpeisova, 2020).

The recognition of the personality in the student gives space for his/her freedom in communication, manifestations of personality, awareness of his/her independence. This does not relieve him/her from the practice of generally accepted moral standards in society. The student's paths to personal development are individually peculiar and at the same time relevant to the original moral and socially significant values. The recognition of the student by the teacher implies a two-way management, namely: mutual understanding between these subjects of the educational and training process (Madike, 1980; Rushton, Murray \& Paunonen, 1983). Therefore, in the process of progressive acceptance by the teacher of the student, it is important to indirectly cause him/her self-criticism, the ability to understand him/herself, to predict reactions to his/her own actions, to anticipate relevant events, interpersonal relationships. So gradually and naturally, the teacher develops the student's social competence - a strong ability, which is based on the specifics of the mental processes of each, emotional response and social experience (Wayne and Youngs, 2003).

The process of recognition can successfully and productively influence the development of the student's personality (Büken et al., 2019). The student should recognize the teacher as a senior and more experienced friend and to trust him/her. Therefore, self-correction is important to the teacher. After all, not only should he/she recognize the student, but also the student should recognize the teacher. Otherwise, the efforts of the teacher will be useless. That is why the teacher should deliberately and purposefully overcome personal shortcomings, try not to show his/her negative qualities in interpersonal relationships with students. Recognition of the student occurs in the process of interpersonal communication with the teacher, which determines the optimal emotional state of the person who teaches and who learns. Such communication can be assessed as professional. It should create the best conditions for the motivation and creative nature of education activities. Therefore, the teacher creates favorable conditions for the student to develop interest in studying, the desire to learn, the domination of positive motivation, and consequently the development of a socially significant personality. Optimal pedagogical communication provides a favourable emotional climate of learning and skills, allows maximum use in the educational process of the personal qualities of the teacher and reveal the individual characteristics of the student. The process of student acceptance is a sincere, transparent relationship between the teacher and the student on the basis of genuine true feelings with the acceptance, understanding and adequate assessment of the student as an individual ( $\mathrm{Li}$ and $\mathrm{Wu}, 2011)$.

The acceptance means an unconditional positive attitude towards the student, regardless of his/her peculiarities, attitude to studying, level of success; it is recognition of his/her right to be as he/she is, with 
the acceptance of his/her positive qualities and disadvantages. The full and unconditional acceptance contributes to his/her self-affirmation, freedom for creative self-realization The teacher's willingness to accept the student includes: positive perception of the student as he/she is; attention to his/her feelings, thoughts, willingness to hear them; willingness to share socially significant values and views, to convince them of expediency and advantages; respect for the student's position, belief in his/her strength and ability. Only in the state of full acceptance, the individual will feel and understand his/her qualities, will become more and more integral person, strive for a certain ideal, will be a self-controlled, expressed individuality, able to confidently and successfully cope with life's difficulties, to perceive better other people.

Using communication as a management tool, not only as a way of transmitting information, but also in order to identify the acceptance of the student and the development of his/her personality, the teacher should consciously use and control his/her own speech, emotional manifestations, which directly or indirectly aimed at the development of interpersonal relationships with students and, ultimately, the development of their personalities. On the basis of educational activities, it is important to organize cooperation with students, during which the teacher and students should understand and support each other in order to achieve the result, taking into account the interests of each other as their own. This requires the mutual activity. Such a management of training and education of students in accordance with their life experience, opportunities, desires and needs, develops their value attitude towards their acquisition of professional competencies as person-centered entities.

\section{CONCLUSION}

The person-centered approach of the teacher to the student is based on three main components: understanding, recognition, acceptance. Based on humanistic pedagogy, each of these components has its own characteristics. In order to understand the student, the teacher uses a set of methods: he/she studies the student, critically and benevolently compiles for him/herself the student's evaluation characteristic, selfcritically assesses him/herself, seeks to achieve mutual understanding; when recognizing the student, the teacher is positively adjusts to his/her right to self-expression and trusts his/her self-improvement; the acceptance of the student by the teacher involves the establishment of a friendly and mutually understanding relationship, the willingness to reveal to young people the best human qualities. Taken together, they constitute, so to speak, the "code" of a professional teacher who is sensitive to students. Such teacher builds the strategy of relationships with them, focusing on the prospect of the individual's development as a fullfledged person, who constantly asserts him/herself through manifestations of his/her feelings, intentions, ways of perceiving the surrounding world and self-realization in it.

Therefore, understanding, acceptance, recognition by the teacher of self-realization of the student, expands the significant space of his/her life, encourages moral and spiritual creativity, and ensures the achievement of higher spiritual goals and humanistic senses of being. The teacher, as the manager of the educational process knowingly or unknowingly declares him/herself as a person and a specialist. Depending on his/her style of managing the educational process, the students develop a certain perception of the teacher and the attitude towards him/her. Hence the effectiveness of the managerial activities of the teacher. Thus, management in education is a mutual process of a person-centered interaction between the teacher and the student. That is why teaching should involve management of the educational process based on personcentered mutual influences between the teacher and the student. In the educational process organized by us, the indirect management of independent individual studies of students was proved by means of tasks of three levels of difficulty: reproductive, reconstructive, and creative. The success of such tasks is increasing in line with the increase in the number of teachers and the number of disciplines in which they use the person-centered approach through direct relationships with students and the mediate and educational tasks for their independent individual work. 


\section{REFERENCES}

Andreyev, V.I. (2012). Pedagogy: A Training Course for Creative Self-Development (p.608). Kazan: Center for Innovative Technologies.

Artemova, L.V. (2012). Higher School Pedagogy and Methodology (p.272). Kyiv: Kendor.

Bekh, I.D. (2015). Selected Scientific Works. Personality Education (p.640). Chernivtsi: Bukrek.

Büken, E., Yaşar, Z.F., Zengin, H.Y., \& Büken, B. (2019). A method suggestion to measure the effectiveness of informed consent during treatment process: A study on university students. Medicine and Law, 38(4), 565-582.

Hlushchenko, N.V., \& Sahaidak, V.O. (2021). Features of administrative liability of legal entities. Legal Horizons, 14(2), 44-49.

Hryniak, A.B., Pleniuk, M.D., \& Lapko, A.H. (2021). Practical-oriented nature of learning as an important component of legal education reform in Ukraine. Journal of the National Academy of Legal Sciences of Ukraine, 28(3), 186-196.

Karimova, B.S., \& Zhetpeisova, N.O. (2020). On innovative pedagogical technologies and training methods. International Journal of Learning and Change, 12(1), 15-24.

Kopochynska, Yu.V. (2020). Theoretical and methodological aspects of application of personal approach in the process of professional education of future specialists in physical therapy, ergotherapy.

Scientific Bulletin of Mukachevo State University. Series "Pedagogy and Psychology", 1(11), 72 75.

Lamke, T. (2015). Personality and teaching success. The Journal of Experimental Education, 20, $217-$ 259.

Law of Ukraine "About the Higher Education”. (2014). Retrieved August 18, 2020, from https://zakon.rada.gov.ua/laws/show/1556-18\#Text

Li, H.Q., \& Wu, Y.Z. (2011). Comparative study of the personality patterns of "good teacher" and "bad teacher" as perceived by college students. Advanced Materials Research, 271-273, 760-763.

Maad, M.R.B. (2021). Embracing balance in early childhood education: The case of awakening to languages pedagogy. International Journal of Learning and Change, 13(1), 92-106.

Madike, F.U. (1980). Teacher classroom behaviors involved in microteaching and student achievement: A regression study. Journal of Educational Psychology, 72, 265-274.

Marchuk, G.F. (2013). Methods of personality oriented teaching in the lessons of the Ukrainian language in the elementary school of intensive pedagogical correction. Retrieved August 18, 2020, from http://lib.iitta.gov.ua/8950/1/посібник Марчук.pdf

Melnyk, N.I. (2016). Preschool Teacher Professional Education in the Western European Countries: Theory and Practice (p.392). Uman: FPE Zhovtyi.

Program of scientific and pedagogical (assistant) practice of students of the magistracy (for all specialties). (2013). Retrieved from http://te.kpi.ua/prog-prov-nauk-ped-prac-mag.pdf

Rashkevych, Yu.M. (2014). Bologna Process and New Paradigm of Higher Education (p.168). Lviv: Lviv Polytechnic Publishing House.

Rushton, J.P., Murray, H.G., \& Paunonen, S.V. (1983). Personality, research creativity, and teaching effectiveness in university professors. Scientometrics, 5, 93-116.

Stryzhak, I. (2007). Practical Management for Local Government Employees (p.195). Kyiv: “UkraineUSA" Foundation.

Wayne, A.J., \& Youngs, P. (2003). Teacher characteristics and student achievement gains: A review. Review of Educational Research, 73, 89-122.

Yakimanskaya, I.S. (2000, September). Technology of Personality-Oriented Education (p.176). Moscow.

Zagorodnya, L.P., \& Tytarenko, S.A. (2010). Pedagogical Mastery of a Preschool Teacher (p.319). Sumy: Universytetska Knyha.

Zub, L.O., Roborchuk, S.V., \& Buzdugan, I.O. (2021). Pedagogical theory and personality development during distance learning among medical university students. Scientific Bulletin of Mukachevo State University. Series "Pedagogy and Psychology”, 7(1), 54-62. 